\title{
Analysis of Influencing Factors Regional Original Revenue (PAD) in The Provincial Government of DKI Jakarta
}

\author{
Febri Umar Doni \\ Master of Accounting Program \\ Sekolah Tinggi Ilmu Ekonomi Indonesia \\ Jakarta, Indonesia
}

\begin{abstract}
The purpose of this study were (1) to Obtain empirical evidence of the influence of the Population against region income, (2) the effect of GRDP against the local revenue, (3) Obtain a picture of the effect of government spending on regional revenue, (4) describes the effect of Population, GRDP and government spending to regional revenue, (5) to analyze the influence of Total Population, GRDP and government expenditure to local revenue. In this sampling technique, Researchers used purposive sampling is done by taking the subject is not based on strata, random or region but is based to Obtain a sample of Jakarta's financial statements that will be Examined are the data of 2001 to 2014. The results Showed that (1) partially contained negative effect but not significant number of inhabitants of the regional income, (2) partially no positive effect but not significant GRDP against the local revenue, (3) partially contained positive and significant impact government expenditure of the local revenue, (4) there is simultaneously a positive and significant influence between Population, GRDP and government spending to regional revenue, (5) the influence of Total Population, GRDP and government spending to local revenue amounted to $92.7 \%$ while The remaining $7.3 \%$ is influenced by other factors outside the models of this study.
\end{abstract}

Keywords-population, GRDP, government expenditure and local revenue $(P A D)$

\section{INTRODUCTION (HEADING 1)}

Development is essentially a process of progress and improvement that continues to lead to the achievement of desired goals. In general the goal to be achieved is the creation of improving the welfare of society equally and fairly. In achieving these objectives, all the potential and existing development resources are allocated effectively and efficiently to increase overall production. Development of a region is determined by the resources owned, especially the source of local revenue that is useful to cover the necessary funding for local government in carrying out its duties. Local governments have greater authority to allocate local budgets in accordance with local needs, as well as to encourage local community participation in development activities.
Local Revenue (PAD) of an area is expected to be a source of financing the implementation of government and regional development to improve the welfare of the community. Bratakusuma (2009: 29) states the Original Revenue is one indicator in measuring the level of autonomy of an autonomous region in the administration of government and development. PRELIMINARY

Development is essentially a process of progress and improvement that continues to lead to the achievement of desired goals. In general the goal to be achieved is the creation of improving the welfare of society equally and fairly. In achieving these objectives, all the potential and existing development resources are allocated effectively and efficiently to increase overall production. Development of a region is determined by the resources owned, especially the source of local revenue that is useful to cover the necessary funding for local government in carrying out its duties. Local governments have greater authority to allocate local budgets in accordance with local needs, as well as to encourage local community participation in development activities.

Local Revenue (PAD) of an area is expected to be a source of financing the implementation of government and regional development to improve the welfare of the community. Bratakusuma (2009: 29) states the Original Revenue is one indicator in measuring the level of autonomy of an autonomous region in the administration of government and development.

In principle, the greater the contribution of Local Revenue in the Regional Budget (APBD), the smaller the level of regional dependence to the central government. Conversely, the lower the contribution of Original Revenue, the greater the dependence of the regions to the central government.

The Original Revenue reflects the independence of a region. Santoso (2012: 1) argues that PAD is a pure source of revenue from the region, which is the main capital for the region as the cost of governance and regional development. 
Sutrisno (2010: 41) distinguishes 2 (two) factors that affect the Local Revenue of a region, namely External Factors and Internal Factors. External factors consist of investment, inflation, Gross Regional Domestic Product (GRDP) and population, while Internal factors consist of facilities and infrastructure, incentives, subsidy receipts, development receipts, human resources, local expenditures, regional regulations, systems and reporting.

Therefore, to be able to know the increase of regional autonomy, Local Revenue can be used as a benchmark, because PAD is an important component that reflects how a region is able to collect and optimize sources of funds to finance local activities (Sutrisno, 2010: 200). Therefore, the authors conclude that research on the Original Revenue is still quite logical for analysis and in-depth study.

Related to this matter, it is necessary to do research to study deeply about the population, GRDP and government expenditure on Local Original Revenue, why the phenomenon happened and how to overcome it in order to achieve the purpose of this research entitled "Analysis of Factors Affecting Local Revenue (PAD) to the Provincial Government of DKI Jakarta ".

\section{A. Identification of Problems}

\section{1) Population (X1)}

The growing number of people will increase the number of workers. An increase in the number of labor allows an area to increase production. The amount of local income can be affected by the population, if the population increases then the income drawn will increase (Halim, 2010).

Based on data from the Central Bureau of Statistics in the DKI Jakarta Provincial Statistics Year 2014, DKI Jakarta is one of the provinces with the highest population density in Indonesia and the DKI Jakarta Provincial Revenue is the largest compared to other provinces in Indonesia.

Based on the above theories and phenomena, the authors suspect that population growth can increase economic activity in producing goods and services, due to the increasing economic activity of a region then the flow of government revenue through the Local Revenue (PAD) also increased.

\section{2) $G R D P(X 2)$}

The high rate of economic growth indicated by the high value of Gross Regional Domestic Product shows that the region is making progress in the economy ([9], 2011).

Based on the PDRB data obtained from BPS, the growth of Jakarta Gross Regional Domestic Product (DKI Jakarta) is always positive and its value is always above other provinces, in line with the fact that the original revenue of DKI Jakarta Province which is PAD with the biggest value compared to other provinces and always increasing every year.

From the theory and phenomenon, the authors suspect that the increase of GRDP value of a region shows an increase in the production of goods and services along with an increase in economic activity of a region, thus causing the flow of local government revenue through Pendapatan Asli Daerah (PAD) also increases.

\section{3) Government Expenditures (X3)}

Based One of the functions of government in development is as a catalyst and facilitator ([5], 2010). Local governments allocate funds in the form of budgets in the Regional Revenue and Expenditure Budget (APBD) to implement the fungi and its role. With the increase of capital expenditure, it will have an impact on the coming period of increasing community productivity and increasing of investor will increase Original Regional Revenue (Abimanyu, 2010).

From the explanation of the theory and phenomenon, the authors suspect that expenditures issued by the local government can increase aggregate spending and enhance the level of economic activity, so that with the increase of economic activity in a region causes the flow of government revenue through the Local Revenue (PAD) also increased.

\section{B. Formulation of the Problem}

1) Is there any influence of the population on the local revenue?

2) Is there any effect of GRDP on local revenue?

3) Is there any influence of government expenditure on local revenues?

4) Is there any influence of population, GRDP and government expenditure on local revenue?

\section{THEORETICAL BASIS}

\section{A. Total population}

According [2] (2012: 159), said that the large population for Indonesia by development planning is seen as a major asset development capital but also as a burden of development.

\section{B. Gross Regional Domestic Product (GRDP)}

Economic growth means the development of activities in the economy that cause goods and services produced in society to increase and prosperity of society increases ([9], 2011: 10). Economic growth is defined as an increase in GDP (Gross Domestic Product) regardless of whether the increase is greater or smaller than the population growth and regardless of whether there is a change in the structure of its economy ([9], 2011: 5). According to Zaris (2010: 87), economic growth is part of the development of people's welfare as measured by the per capita gross regional domestic growth (GRDP per capita).

\section{Government Expenditures}

First, Expenditure by the government shows its role in the economy In order to achieve the condition of a prosperous society. According [3] (2009: 56) Government has 4 roles: 
1) The role of allocation, namely the role of government in allocating existing economic resources for utilization can be optimal and support production efficiency.

2) The distributive role, ie the role of government in distributing resources, opportunities and economic outcomes fairly and fairly.

3) The stabilitative role, namely the role of the government in maintaining economic stability and restoring it if it is in a state of equilibrium.

Dynamic role, namely the role of government in moving the process of economic development in order to more quickly grow, develop and progress.

\section{Local Original Revenue (PAD)}

Local revenue is regional revenue from various local government efforts to raise funds for the purposes of the region concerned in financing its routine or developmental activities, comprising local taxes, regional fees, the share of regional-owned business profits, and other legally acceptable local revenue (Sutrisno, 2010: 168). Indigenous revenues are defined as regional revenues that depend on the state of the economy in general and the potential of local revenue sources themselves. Sutrisno (2010: 200) local revenue is an income that shows the ability of an area to collect sources of funds to finance regional activities. So the definition of local revenue can be said to be a regular income from local government efforts in exploiting the potential of financial resources to finance its duties and responsibilities. According to Article 285 paragraph (1) of Law Number 23 Year 2014 on Regional Government jo. Law Number 2 Year 2015 on Amendment of Law Number 23 Year 2014 on Regional Government, Local Original Income derives from: 1. Regional Taxes, 2. Local Levies, 3. Results of Management of Regional Wealth separated 4. Others Revenue Original Legal Region. Regional Tax is a dues that can be imposed to the taxpayer by the government with the remuneration that can not be directly appointed. In essence the tax has two main roles as a source of state revenue (budget function) and as a tool to regulate (regulatory function) ([7, 8], 2009: 135).

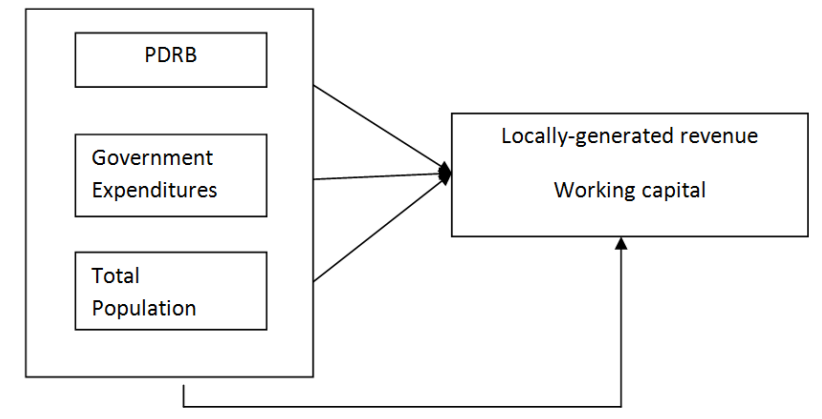

Fig. 1. Research Framework

\section{RESEARCH METHODS}

[10] (2009: 1) defines "Research method is basically a scientific way to get data with the purpose and usefulness tetentu". In this research, researcher use Verikatif method with Quantitative approach obtained from documentation.

[10] (2009: 61) explains that the verification method is testing the research hypothesis through statistical analysis tools. This research is intended to provide an explanation by way of measuring carefully against a particular phenomenon and explain the causal relationship between variables through hypothesis testing using statistical tests.

\section{A. Taking Sample Criteria}

Sukaran (2009: 123), defines the sample is part of the population and consists of a select number of members of the population ". According to Arikunto (2009: 131), the sample is part or representative of the population under study. In this study, the researchers took the sample of the last 14 years data Realization of Regional Budgets and Statistics DKI (Special Territory) Jakarta Year 2001-2014.

In this sampling technique, researcher use purposive sampling that is done by taking subject not based on strata, random or area but base to get sample.

Reasons for Data Selection Year 2001 up to Year 2014 in this research are due:

1) Financial Data both Central and Regional Government is the latest or latest data, so it is expected to reflect the current condition.

2) Conditions in 2001 were three years after the monetary crisis of 1998 in Indonesia and some countries in Southeast Asia, so it is believed to be able to avoid the existence of extreme data at the time of analysis.

3) In 2001, the effective implementation of regional autonomy in Indonesia, in accordance with Law Number 22 Year 1999 regarding Regional Government and Law Number 25 Year 1999 Concerning Financial Balance between Central and Regional Governments, in view of the provisions of the transition in the two laws regulating that the effective implementation of the maximum 2 (two) years since the official enacted.

4) In the year 2000, there was a change of the State Budget (APBN / D) State Budget (APBN / D) format from Taccount (Balance Budget) to I-account (Government Financial Statistic), so there is a difference of APBN / D data before and after Fiscal Year 2000 .

5) In the year 2000 there was a change of 1 year APBN / D from 1 April s.d. March 31 to January 1 s.d. December 31, so that the APBN / D Year 2000 as the transitional year is only 9 months (April 1-December 31).

\section{B. Analisis Method}

\begin{tabular}{|l|c|c|c|}
\hline \multicolumn{4}{|c|}{ Coefficients } \\
\hline Model & $\begin{array}{c}\text { Un standardized } \\
\text { Coefficients }\end{array}$ & $\begin{array}{c}\text { Standardized } \\
\text { Coefficients }\end{array}$ & \\
\hline
\end{tabular}




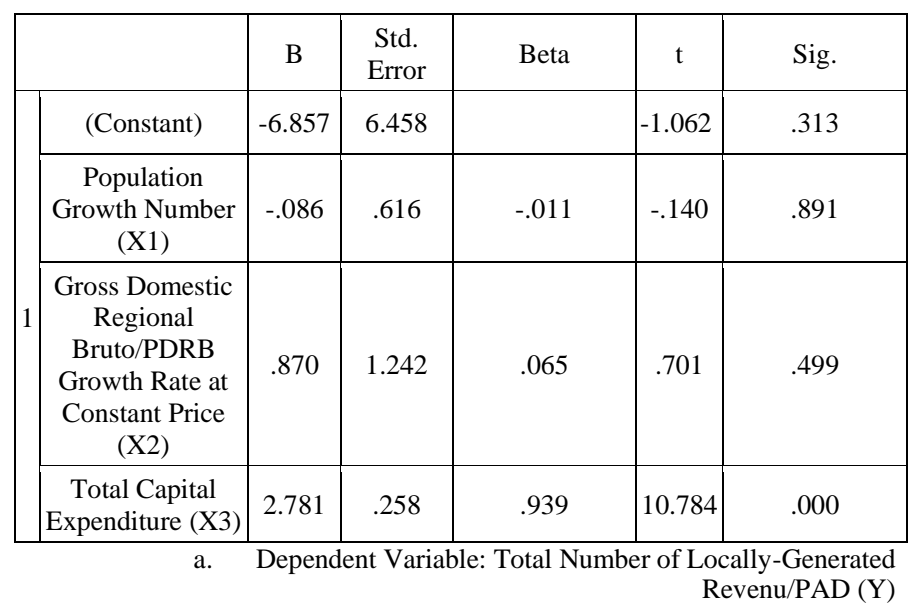

Source: Processed data 2015

Define Thus, multiple linear regression equations can be constructed as follows:

Number of Locally-Generated Revenue/PAD $=-6,857-$ 0,086 (JP) + 0,870 Gross Regional Domestic Product (GRDP) $+2,781(\mathrm{BM})$.

Based on the regression equation it can be seen that the constant value of -6.857 has meaning if the number of Population Growth, GRDP Growth Rate based on Constant Price and Total Capital Expenditure is zero, then the Total Regional Revenue (PAD) is -6.857 .

The value of the regression coefficient number of Population Growth of -0.086 means that if the number of Population Growth fell by one percent, the PAD rose by 0.086 trillion Rupiah with the assumption that other variables are constant.

The value of regression coefficient number GDP growth at constant prices of 0.870 means if the GDP growth rate on the basis of Constant Price increases by one percent, then the Total Revenue Total of the original increase by Rp. 0.870 trillion.

The value of regression coefficient number Total Capital Expenditure to the total PAD of 2.781 has meaning if the number of Capital Expenditures increased by one trillion Rupiah, then the number of Total Revenue Original Area rose by Rp. 2.781 trillion.

\section{Number of Populationnot Affect Significantly to Local Original Income}

The $t$ test in this research is used to find out whether the independent variable has an effect on the dependent variable. Based on table 4.8, it can be interpreted the first hypothesis test $\left(\mathrm{Ha}_{1}\right.$ ) shows the result that the variable number of Population Growth has coefficient of -0.086 and significance of $0.891>\alpha=0.05$ which means the number of population growth has a negative but not significant to Total Local Revenue (PAD). This indicates that the Population is not considered as the main reference in increasing or decreasing
PAD. It shows that the high number of DKI Jakarta Provinces can not increase or decrease PAD because basically the wheels of the economy in DKI Jakarta Province are also driven by people living outside Jakarta, especially in buffer areas around DKI Jakarta (Bogor, Depok, Tangerang and Bekasi). This result is supported by research by [1] (2014) which states that the population has no significant influence to the original income of the regency in Gresik, Bangkalan, Mojokerto, Mojokerto, Surabaya, Sidoarjo and Lamongan.

\section{Gross Regional Domestic Bruto (PDRB) Not Influential Significantly to Local Own Revenue}

Testing the second hypothesis $\left(\mathrm{Ha}_{2}\right)$ shows the result that the variable rate GDP growth on the basis of Constant Price has a value of coefficient of 0.870 and a significance level of $0.499>\alpha=0.05$ which means that the GDP growth rate on the basis of Constant Price has a positive but not significant at the Total Regional Original Revenue (PAD). As explained earlier, the GRDP rate in DKI Jakarta Province is quite high compared to other provinces in Indonesia, so the authors chose to use PDRB growth rate in this research, in order to give the result which represent the actual condition. This is supported by research through the journal GigihArifRiyanto (2006), in his research entitled "Analysis of Factors Affecting Local Own Revenue (PAD) of Yogyakarta Province 1980-2002" with the results showed that GRDP has no effect on PAD Real in DIY Province. Similarly, research conducted by EndangSugiarti (2008) based on the results of this study it can be concluded that Gross Regional Domestic Product (PDRB) in Magelang Regency has no significant effect on PAD Magelang District.

High or low GDP growth in the Province of DKI Jakarta, for now does not affect the size of PAD significantly. One of them can be caused by PAD components that are directly related to the level of economic growth, which has not been optimally explored its potential. Based on data from the realization of APBD of DKI Jakarta Province, from year to year local tax became the biggest contributor of PAD. Other PAD components such as regional levies, revenues from separated area wealth management and other PADs, are only able to make a small contribution to PAD in DKI Jakarta Province. The average accumulated local revenue from sectors other than local taxes on PAD over the last five years only reached 14.7 percent.

In addition, the revenue from the local tax sector actually has a greater potential than that already realized, it can be seen from the DKI Jakarta Provincial Financial Statement Data of Fiscal Year 2014, that the realization of local tax revenue on target only touches the number 83.23 percent.

\section{Government Spending Influences Significantly to Local Income}

The second hypothesis test (Ha.3) shows the result that the variable number of Capital Expenditure has a coefficient value of 2.781 and a significance level of $0.000<\alpha=0.05$ which means that the Total Capital Expenditure has positive and significant influence on the Total Regional Original Income (PAD ). This gives an indication that the PAD in the 
Provincial Government of DKI Jakarta is determined by the amount of Capital Expenditure issued. Increasing the expenditure or spending of DKI Jakarta Provincial Government will affect the increase of Original Regional Revenue, meaning that expenditure issued by DKI Jakarta Provincial Government especially for investment or asset purchase and infrastructure development will increase PAD. As [7, 8] (2009) suggests, government expenditures can be valued as an investment to add strength and economic resilience in the future. The development of infrastructure and the improvement of facilities and infrastructures for the community will be able to encourage the acceleration of economic cycle in various sectors so that in the end will be able to increase the original income of the region.

Addressing the problems in Jakarta by local governments, such as traffic jams, floods and slums with infrastructure development and improvements to facilities and infrastructure, will make DKI Jakarta the ideal metropolitan city, both as a center of government and a center of economic activity. Indirectly will attract investors both from domestic and abroad to invest in the Province of DKI Jakarta. So that in the endincrease the potential of the Original Revenue. The results of this study are supported by [1] (2014), [11] (2013) and [4] (2013), which states that government spending has a positive and significant influence on Local Own Revenue (PAD).

\section{CONCLUSION AND SUGGESTION}

\section{A. Conclusion}

1) Partially Influence $X_{1}$ to $Y$

Partially there is a negative but not significant influence of the number of Population to Local Original Income.

It shows that the high number of DKI Jakarta Provinces can not increase or decrease PAD because basically the wheels of the economy in DKI Jakarta Province are also driven by people living outside Jakarta, especially in buffer areas around DKI Jakarta (Bogor, Depok, Tangerang and Bekasi).

2) Partially Effect $X_{2}$ on $Y$

Partially there is a positive but not significant effect of GRDP on Local Revenue.

This means that the high or low growth of GRDP in the Province of DKI Jakarta, for now does not affect the size of PAD significantly. One of them can be caused by PAD components that are directly related to the level of economic growth, which has not been optimally explored its potential.

\section{3) Partially Influence $X_{3}$ on $Y$}

Partially there is a positive and significant influence of Government Expenditure on Local Original Income.

This gives an indication that the PAD in the Provincial Government of DKI Jakarta is determined by the amount of Capital Expenditure issued. Increasing the expenditure or spending of DKI Jakarta Provincial Government will affect the increase of Original Regional Revenue, meaning that expenditure issued by DKI Jakarta Provincial Government especially for investment or asset purchase and infrastructure development will increase PAD.
4) Simultaneously Influence $X_{1}, X_{2}, X_{3}$ to $Y$

Simultaneously there is a positive and significant influence between the Number of Population, GRDP and Government Expenditure on Local Original Income.

\section{B. Suggestion}

1) Operational Suggestions

a) Variable of Population does not significantly affect the local revenue (PAD), so the Jakarta Provincial Government does not have to worry about the high population of Jakarta, hampering the increase of PAD. However, what needs to be done is how the Provincial Government of DKI Jakarta encourages buffer areas around DKI Jakarta (Bogor, DepokTangerang and Bekasi) to develop potential, promote the economy and build infrastructure in the area, so it is expected to continue to have a positive impact on the economy in general and the Original Revenue of DKI Jakarta Province in particular.

b) The GRDP variable has no significant effect on the Local Own Revenue (PAD), the Provincial Government of DKI Jakarta should optimize the Local Revenue from sectors directly related to economic growth, such as income from the profit share of Regional Owned Enterprises (BUMD), revenue from levies, income of short-term investments (stocks / bonds) as well as income from long-term non-permanent investments (other than BUMD's capital participation). Thus, it will provide an alternative for the Provincial Government of DKI Jakarta, so that the original revenues are not too dependent on local tax revenues, as it has been so far. Local taxes actually still have room for improvement, given the realization of Year 2014 has not reached $100 \%$ of the target set. So it is expected that the high rate of PDRB will be able to significantly affect the PAD in DKI Jakarta Province.

c) Government Expenditure Variable Influence Significantly to Local Own Revenue (PAD), it is better to increase Government Expenditure especially Capital Expenditure issued by DKI Jakarta Provincial Government, considering that every investment or asset purchase and infrastructure development have direct influence in increasing PAD in DKI Jakarta Province. The relatively low rate of capital expenditure absorption in 2014 is about $40 \%$ strived not to recur in the years to come. In addition, the remaining budget financing (SILPA) of DKI Jakarta Province which has tended to increase in recent years should be prioritized for the purchase of productive fixed assets or investment in the form of infrastructure development. So, the original revenue (PAD) that in DKI Jakarta Province can continue to increase every year.

\section{2) Science Development Advice}

a) Further Research 
Febri Umar Doni

- For the next researcher who is interested in similar problems, especially in DKI Jakarta Province, it is suggested that the research will be conducted using population data which has been grouped based on income bracket (poor, middle and rich class), so it is known which population group has a significant effect on the original income area (PAD). Besides, it is necessary to examine the different variables such as inflation, per capita income, household expenditure or consumption, gross fixed capital formation, export-import and others. So it is known also, other variables that have significant effect on Local Revenue (PAD) besides Government Expenditures.

- A more complete and in-depth discussion by adding independent variables or other dependent variables in terms of size or type, as well as nonfinancial variables such as government policy, government budgeting, political and social aspects.

\section{b) Education}

The results of this study can be used as a source of reference to add insight and knowledge in order to increase in-depth knowledge, especially related to the factors that affect the Original Revenue.

\section{References}

[1] Hartyanto, Adi. Studi tentang Pertumbuhan Ekonomi, Belanja Langsung Pemerintah Daerah dan Jumlah Penduduk terhadap Pendapatan Asli Daerah (PAD) pada Satuan Wilayah Pembangunan Gerbangkertosusila". 2014.
[2] Budiharjo, Eko (Ed.). Arsitektur Pembangunan dan Konservasi. Penerbit Djambatan. Jakarta. 2012.

[3] Dumairy. Perekonomian Indonesia. Erlangga. Jakarta. 2009.

Gde Bhaskara Perwira Jaya dan A.A. Bagus Putu Widanta, Analisis Faktor-faktor yang mempengaruhi terhadap Pendapatan Asli Daerah (PAD) kota Denpasar". E-Jurnal EP UNUD, 3 (5) : 201-208 ISSN:2303-0178.

Hakim. Jumlah Penduduk Dunia. Rustam dan Utomo, Hardi, Komponen Perancangan Arsitektur. Jakarta. 2010.

[4] Harry A.P. Sitaniapessy. Pengaruh pengeluaran pemerintah terhadap PDRB dan Pendapatan Asli Daerah (PAD)”. Jurnal Economia, Volume 9, Nomor 1, April. 2013.

[5] Mangkosoebroto, Guritno. Ekonomi Publik, Edisi 3, BPFE Yogyakarta, Yogyakarta. 2010.

[6] Samuelson, Paul A dan William Nordhaus. Makro Ekonomi Edisi 14. Erlangga. Jakarta. 2010.

Soetrisno, P.H. Dasar-Dasar Evaluasi Proyek dan Manajemen Proyek, Cetakan II, Andi Offset, Yogyakarta. 2010.

[7] Suparmoko, M. Ekonomi Publik. Untuk Keuangan dan Pembangunan Daerah. Andi. Yogyakarta. 2009.

[8] Suparmoko, M. dan Irawa. Ekonomi dan Pembangunan. Libarty. Yogyakarta. 2009

[9] Sukirno. Pengantar Teori Mikro Ekonomi. Edisi Ketiga. Grafindo. Jakarta. 2009.

Suryana. Metode Penelitian untuk Skripsi dan Tesis Bisnis. PT Raja Grafindo Persada. Jakarta. 2009.

[10] Sugiyono. Metode Penelitian Kuantitatif kualitatif dan R\&D. Alfabeta. Bandung. 2009

Suharsimi Arikunto. Prosedur Penelitian Suatu Pendekatan Praktis. Yogayakarta: Bina Aksara. 2009.

Supangat, Adi. Statistika untuk Ekonomi dan Bisnis. Bandung: Pustaka. 2009

[11] Tohir. Pengaruh pengeluaran pemerintah, PDRB dan jumlah penduduk terhadap pendapatan asli daerah (PAD) di kota Pontianak. Jurnal Curnomic. Volume 2 No. 3 Tahun 2013. 2013. 